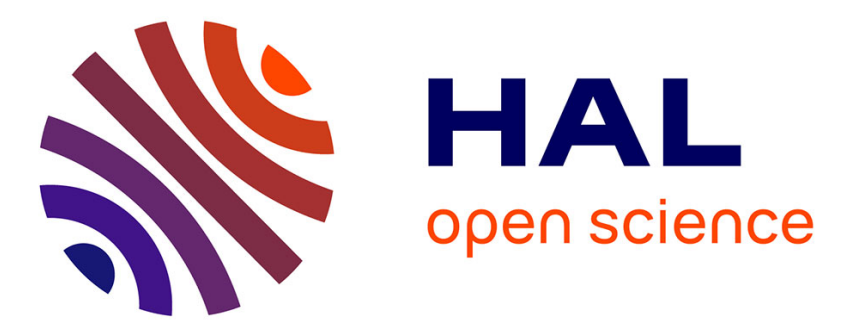

\title{
Site occupancies in synthetic monoclinic amphiboles: Rietveld structure refinement and infrared spectroscopy of (nickel, magnesium, cobalt)-richterite.
}

Giancarlo Della Ventura, Jean-Louis Robert, Mati Raudsepp, Franck C. Hawthorne, Mark D. Welch

\section{To cite this version:}

Giancarlo Della Ventura, Jean-Louis Robert, Mati Raudsepp, Franck C. Hawthorne, Mark D. Welch. Site occupancies in synthetic monoclinic amphiboles: Rietveld structure refinement and infrared spectroscopy of (nickel, magnesium, cobalt)-richterite.. American Mineralogist, 1997, 82, pp.291-301. hal-00077576

\section{HAL Id: hal-00077576 \\ https://hal-insu.archives-ouvertes.fr/hal-00077576}

Submitted on 31 May 2006

HAL is a multi-disciplinary open access archive for the deposit and dissemination of scientific research documents, whether they are published or not. The documents may come from teaching and research institutions in France or abroad, or from public or private research centers.
L'archive ouverte pluridisciplinaire HAL, est destinée au dépôt et à la diffusion de documents scientifiques de niveau recherche, publiés ou non, émanant des établissements d'enseignement et de recherche français ou étrangers, des laboratoires publics ou privés. 


\title{
Site occupancies in synthetic monoclinic amphiboles: Rietveld structure refinement and infrared spectroscopy of (nickel, magnesium, cobalt)-richterite
}

\author{
Giancarlo Della Ventura, ${ }^{1}$ Jean-Louis Robert, ${ }^{2}$ Mati Raudsepp, ${ }^{3}$ \\ Frank C. Hawthorne, ${ }^{4}$ and Mark D. Welch ${ }^{5}$
}

\author{
'Dipartimento di Scienze Geologiche, Terza Università di Roma, Viale Ostiense 169, Rome, I-00154, Italy \\ ${ }^{2}$ Centre pour la Synthese et la Chimie des Mineraux, CNRS, 1A, rue de la Ferollerie, Orleans cedex 2, France \\ ${ }^{3}$ Department of Earth and Ocean Sciences, University of British Columbia, Vancouver, British Columbia V6T 1Z4, Canada \\ ${ }^{4}$ Department of Geological Sciences, University of Manitoba, Winnipeg, Manitoba R3T 2N2, Canada \\ ${ }^{5}$ Department of Mineralogy, The Natural History Museum, Cromwell Road, London SW7 5BD, U.K.
}

\begin{abstract}
Amphiboles were synthesized at $750{ }^{\circ} \mathrm{C}, 1 \mathrm{kbar}\left(\mathrm{H}_{2} \mathrm{O}\right)$ on the binary joins (nickel, magnesium)-richterite and (magnesium, cobalt)-richterite. Structural variations and site occupancies were characterized by Rietveld structure refinement, with final $R_{\text {Bragg }}$ indices in the range $4-9 \%$, and by powder infrared spectroscopy in the principal $\mathrm{OH}$-stretching region. Site-occupancy refinement of $\mathrm{Ni}-\mathrm{Mg}$ and $\mathrm{Mg}$-Co distributions give the partition coefficients over M1,3 and M2 where $K^{\mathrm{M} 2+}=\left(\mathrm{M}^{2+} / \mathrm{Mg}\right)_{\mathrm{M} 1,3} /\left(\mathrm{M}^{2+} / \mathrm{Mg}\right)_{\mathrm{M} 2}$, and $\mathrm{M}^{2+}=\mathrm{Ni}^{2+}$ or $\mathrm{Co}^{2+}, K_{\mathrm{d}}^{\mathrm{Ni}}=2.98 \pm 0.37$ and $K_{\mathrm{d}}^{\mathrm{Co}}=1.34 \pm 0.31$. Both $K_{\mathrm{d}}$ values are greater than 1.0, whereas ${ }^{[6]} r\left(\mathrm{Ni}^{2+}\right)<{ }^{[6]} r(\mathrm{Mg})<{ }^{[6]} r\left(\mathrm{Co}^{2+}\right)$; this indicates that cation size is not the primary factor affecting the ordering of $\mathrm{Ni}-\mathrm{Mg}$ and $\mathrm{Mg}$-Co over the octahedral sites. The infrared spectra of intermediate binary compositions show fine structure caused by ordering of $\mathrm{Ni}$ $\mathrm{Mg}$ or $\mathrm{Mg}$-Co over the M1,3 sites and by ordering of $\mathrm{Na}$ and $\square$ (vacancy) at the A site; thus intermediate compositions show an eight-band spectrum in the principal $\mathrm{OH}-$ stretching region. Precise band intensities were derived by nonlinear least-squares fitting of Gaussian band shapes to the observed spectra. The relative observed intensities of the combinations of bands $3 I_{\mathrm{o}}^{\mathrm{A}}+2 I_{\mathrm{o}}^{\mathrm{B}}+I_{\mathrm{o}}^{\mathrm{C}}$ and $I_{\mathrm{o}}^{\mathrm{B}}+2 I_{\mathrm{o}}^{\mathrm{C}}+3 I_{\mathrm{o}}^{\mathrm{D}}$ are in accord with the equations of Burns and Strens (1966), indicating that there is no significant variation in molar absorptivity with frequency (energy) for individual bands within a single sample (spectrum). Combined with the results of Skogby and Rossman (1991) on polarized single-crystal infrared spectra of amphiboles, this result suggests that different local configurations of M1,3 cations in amphiboles couple such that the transition probabilities of the associated $\mathrm{OH}$ groups are equal.
\end{abstract}

\section{INTRODUCTION}

The experimental techniques by which synthetic amphiboles are characterized have considerably increased in number during the last decade (Hawthorne 1983a; Graham et al. 1989; Raudsepp et al. 1991; Della Ventura 1992). The standard methods of powder X-ray diffraction and optical microscopy have been augmented by single-crystal X-ray diffraction (e.g., Boschmann et al. 1994; Oberti et al. 1995), infrared (Robert et al. 1989; Della Ventura 1992; Della Ventura and Robert 1990), Raman (Della Ventura et al. 1991) and MAS NMR spectroscopies (Raudsepp et al. 1987a; Welch et al. 1994), EXAFS and XANES (Mottana et al. 1990; Paris et al. 1993), and HRTEM (Maresch and Czank 1983, 1988; Maresch et al. 1994; Ahn et al. 1991). The Rietveld method (Rietveld 1969; Young et al. 1977) is proving to be very useful for the characterization of cation site occupancies and bulk compositions in synthetic amphiboles (Raudsepp et al. 1987a, 1987b; Della Ventura et al. 1993a, 1993b; Robert et al. 1993; Jenkins and Hawthorne 1995). With reference to the present study, Della Ventura et al. (1993b) characterized the ordering behavior in synthetic (nickel, magnesium, cobalt)-potassiumrichterite and showed that $\mathrm{Ni}-\mathrm{Mg}$ and $\mathrm{Mg}$-Co show ideal distributions over the M1,3 and M2 sites, with $K_{\mathrm{d}}$ values of 4.26 and 1.92, respectively. Here, we present analogous results for the solid-solution series (nickel, magnesium)and (magnesium, cobalt)-richterites with end-member compositions richterite $\left[\mathrm{Na}(\mathrm{NaCa}) \mathrm{Mg}_{5} \mathrm{Si}_{8} \mathrm{O}_{22}(\mathrm{OH})_{2}\right]$, Nirich richterite $\left[\mathrm{Na}(\mathrm{NaCa}) \mathrm{Ni}_{5} \mathrm{Si}_{8} \mathrm{O}_{22}(\mathrm{OH})_{2}\right]$, and Co-rich richterite $\left[\mathrm{Na}(\mathrm{NaCa}) \mathrm{Co}_{5} \mathrm{Si}_{8} \mathrm{O}_{22}(\mathrm{OH})_{2}\right]$ and compare the results with data for the analogous potassium-richterite series.

\section{EXPERIMENTAL DETAILS}

Details of synthesis procedures are given by Della Ventura et al. (1993b). Compositions were prepared along the binary joins (nickel, magnesium)-richterite and (magne- 
TABLE 1. Data collection and Rietveld structure-refinement details for synthetic amphiboles along the joins (nickel, magnesium)and (magnesium, cobalt)-richterite

\begin{tabular}{|c|c|c|c|c|c|c|c|c|c|c|c|}
\hline & $\operatorname{Mg}(100)$ & $\mathrm{Ni}(20)$ & $\mathrm{Ni}(40)$ & $\mathrm{Ni}(60)$ & $\mathrm{Ni}(80)$ & $\mathrm{Ni}(100)$ & $\mathrm{Co}(20)$ & Co(40) & Co(60) & Co(80) & Co(100) \\
\hline Scan range $\left({ }^{\circ}\right)$ & $9-100$ & $9-100$ & $9-100$ & $9-100$ & $9-100$ & $9-100$ & $9-100$ & $9-100$ & $9-100$ & $9-100$ & $9-100$ \\
\hline Step interval $\left({ }^{\circ} 2 \theta\right)$ & 0.10 & 0.10 & 0.10 & 0.10 & 0.10 & 0.10 & 0.10 & 0.10 & 0.10 & 0.10 & 0.10 \\
\hline Integration time/step (s) & 5 & 5 & 5 & 5 & 5 & 5 & 5 & 5 & 5 & 5 & 5 \\
\hline Unique refl. & 518 & 517 & 516 & 515 & 514 & 514 & 517 & 518 & 518 & 521 & 521 \\
\hline Structural param. & 38 & 38 & 38 & 38 & 37 & 38 & 38 & 38 & 38 & 38 & 38 \\
\hline Experimental param. & 13 & 13 & 13 & 13 & 13 & 13 & 13 & 13 & 13 & 13 & 13 \\
\hline $\mathrm{N}-\mathrm{P}$ & 860 & 860 & 860 & 860 & 861 & 860 & 860 & 860 & 860 & 860 & 860 \\
\hline$R_{\mathrm{p}}(\%)$ & 9.99 & 6.55 & 7.80 & 6.75 & 6.47 & 5.86 & 7.85 & 7.30 & 7.16 & 7.05 & 7.07 \\
\hline$R_{\mathrm{wp}}(\%)$ & 12.93 & 8.56 & 10.25 & 9.00 & 8.50 & 7.84 & 10.36 & 9.76 & 9.50 & 9.00 & 9.03 \\
\hline$R_{\text {Bragg }}(\%)$ & 6.28 & 4.65 & 6.90 & 5.61 & 4.87 & 4.14 & 6.26 & 6.27 & 7.47 & 7.17 & 8.85 \\
\hline D-W d-statistic & 1.44 & 1.38 & 1.10 & 1.38 & 1.31 & 1.52 & 1.54 & 1.54 & 1.56 & 1.74 & 1.68 \\
\hline Esd mult. & 1.60 & 1.50 & 1.84 & 1.59 & 1.53 & 1.47 & 1.44 & 1.53 & 1.46 & 1.37 & 1.39 \\
\hline
\end{tabular}

sium, cobalt)-richterite in steps of 1 apfu of the substituting octahedral cation. Synthesis was performed at 750 ${ }^{\circ} \mathrm{C}$ and $P_{\mathrm{H}_{2} \mathrm{O}}=1 \mathrm{kbar}$; samples were removed from the furnace at the end of the experiment and allowed to cool under pressure. X-ray diffraction data were collected as described by Della Ventura et al. (1993b). Information pertinent to data collection is given in Table 1.

For scanning electron microscopy (SEM) study, the powdered experimental products were mounted on carbon tape on a brass substrate $(\mathrm{Cu}, \mathrm{Zn})$ to avoid extraneous $\mathrm{Al} K \alpha \mathrm{X}$-rays (conventional SEM stubs are $\mathrm{Al}$ ). Quantitative image-analysis work was not possible, because the grey-level contrast range from topography in the backscattered-electron image of the grains is generally greater than that resulting from atomic contrast. A bulk EDS spectrum of each run product was acquired from thousands of grains by rastering the beam at relatively low magnification (about $1000 \times$ ); this represents the bulk composition of the product plus extraneous phases such as capsule fragments and mortar contamination. Additional spectra for the same length of time (200 s) were acquired from single amphibole grains with a focused beam. Superimposing the spectra after scaling to a large peak $(\mathrm{Si})$ indicated whether the amphibole is on composition or not (taking into account the mechanical contamination).

HRTEM observations were made using a JEOL 200CX transmission electron microscope operated at $200 \mathrm{kV}$ and having a $\pm 30^{\circ}$ tilt about two orthogonal axes. All samples were very beam sensitive, and a $70 \mu \mathrm{m}$ condensor aperture was used to minimize beam damage. High-resolution images were formed from diffracted beams that passed through a $40 \mu \mathrm{m}\left(0.45 \AA^{-1}\right)$ objective aperture. Crystallites were dispersed in dry alcohol and sedimented onto a $3 \mathrm{~mm}$ holey-carbon copper grid (Agar products) using a pipette.

The structures of the synthetic amphiboles were refined by the Rietveld method using the program DBWS9006PC (Sakthivel and Young 1991), which is based on the program DBW 2.9 (Wiles and Young 1981). Initial structural parameters were taken from the single-crystal study of synthetic fluor-richterite (Cameron et al. 1983). Isotropic displacement factors were fixed at average val- ues for the specific sites in the amphibole structure (Hawthorne 1983b). During initial refinement, the A cation was fixed at the A2/m site (Hawthorne and Grundy 1972). Refinements were then repeated, allowing the A cation to occupy the A2 site along the twofold axis. Better agreement was obtained with this second model, and all subsequent refinements were made with the A cation at the A2 site. Information pertinent to structure refinement is given in Table 1.

For FTIR study, the samples were prepared as $\mathrm{KBr}$ pellets using the procedure of Robert et al. (1989). Spectra in the range $4000-3000 \mathrm{~cm}^{-1}$ were recorded on a Perkin Elmer model 1760 spectrometer equipped with a DTGS detector and a $\mathrm{KBr}$ beamsplitter and operating at a nominal resolution of $1 \mathrm{~cm}^{-1}$. Digitized spectra (average of 64 scans) were fitted by interactive optimization followed by least-squares refinement. The background was modeled as linear, and all peaks were modeled as symmetric Gaussians (Strens 1974). The distribution of absorption, $y$, as a function of energy (wavenumber, $x$ ) is described by the relationship $y=A \exp \left[-0.5(x-P / W)^{2}\right]$, where $A$ is the amplitude, $P$ is the peak centroid, and $W$ is the full-width at half-maximum height (FWHM). The spectra were fitted to the smallest number of peaks needed to get an accurate description of the spectral profile. For intermediate compositions, all parameters were well defined by the envelope of the spectrum, and all peak parameters could be refined unconstrained. For compositions close to the end-members, the weak bands tended to merge with the background if all parameters were refined unconstrained; consequently, for the weak bands, the positions were fixed at the values determined for those spectra in which the corresponding peaks are intense, and the band widths, $W$, were constrained to be equal to the width of the same band.

\section{EXPERIMENTAL RESULTS}

Single-phase experimental products of amphibole were obtained for all starting compositions, indicating complete solid solution along both joins under the experimental conditions used. Additional phases were not detected with the use of a binocular microscope or by X-ray powder diffraction, but SEM examination showed the 

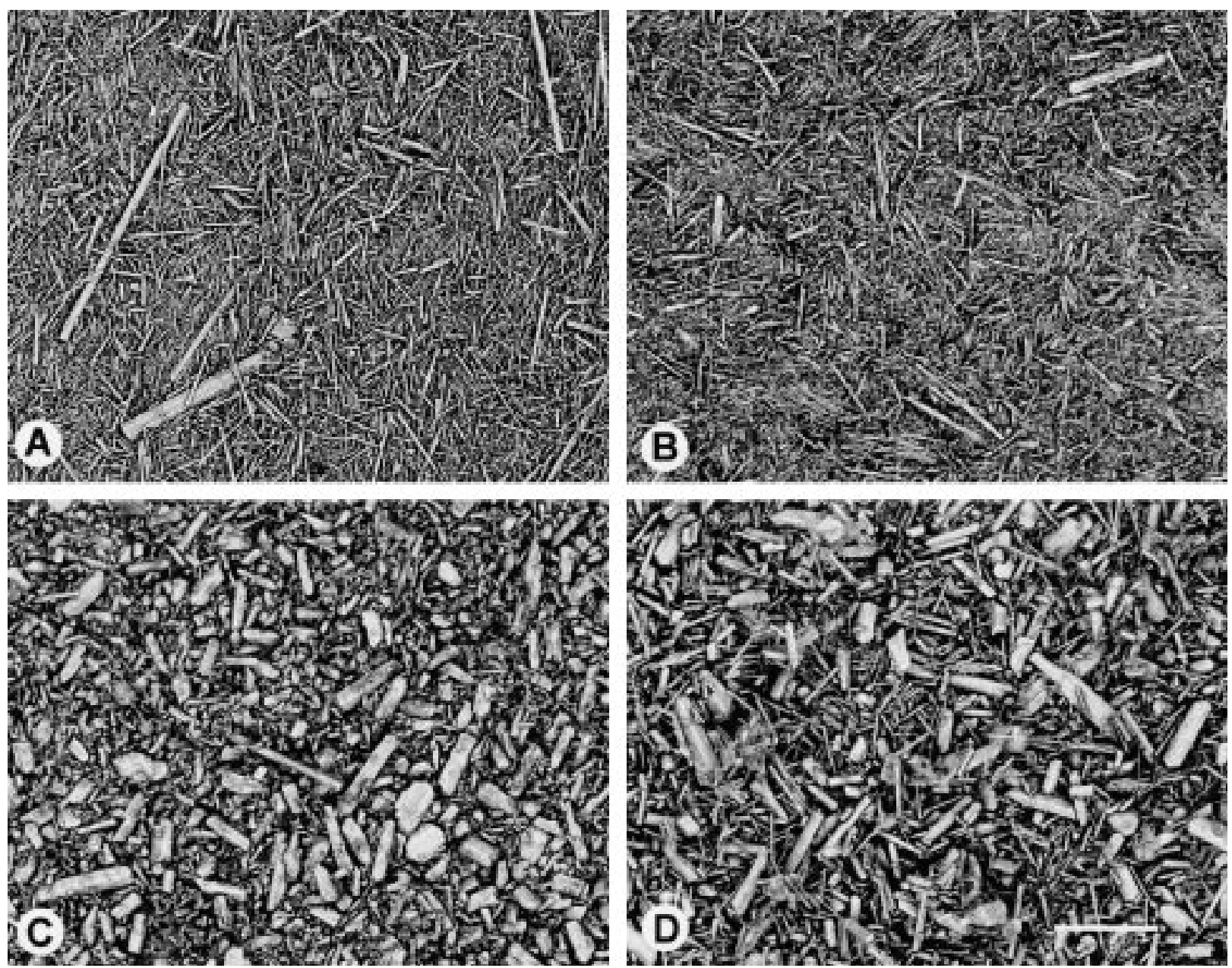

Figure 1. SEM images of synthetic (nickel, magnesium, cobalt)-richterite: (A) richterite; (B) nickel-richterite; (C) cobalt-richterite; (D) intermediate (magnesium, cobalt)-richterite; the scale bar is $20 \mu \mathrm{m}$.

presence of variable amounts of $\mathrm{Al}_{2} \mathrm{O}_{3}(0-<5 \%)$, which presumably originated from grinding the sample in a corundum mortar. Very minor $\mathrm{SiO}_{2}$ in some samples presumably resulted from grinding in an agate mortar. Sample $\operatorname{Mg}(100)$ consists of very acicular amphibole crystals averaging 1-2 $\times 10 \mu \mathrm{m}$, with a maximum size of $4 \times$ $50 \mu \mathrm{m}$ (Fig. 1a). Ni(100) consists of very acicular amphibole crystals varying in size from $1 \times 10 \mu \mathrm{m}$ to $4 \times$ $20 \mu \mathrm{m}$ (Fig. 1b). Co(100) amphibole is generally stubby to prismatic, ranging in size from $2 \times 5 \mu \mathrm{m}$ to $10 \times 20$ $\mu \mathrm{m}$, again with some $\mathrm{Al}_{2} \mathrm{O}_{3}$ present (Fig. 1c). Intermediate compositions have similar morphology (Fig. 1d). Redox conditions were close to that of the $\mathrm{Ni}-\mathrm{NiO}$ buffer. The color of the experimental product was green $(\mathrm{Ni}-\mathrm{Mg}$ series) or violet-pink ( $\mathrm{Mg}$-Co series), with the intensity of color increasing with the content of the transition-metal present. No trace of unreacted material was detected. High-resolution TEM images of various (nickel, magnesium, cobalt)-richterite samples are shown in Figure 2. No chain-multiplicity faults, chain-arrangement faults, or additional phases were observed by TEM in any of the samples. The patchy contrast in Figure $2 b$ is due to differential beam damage.

Unit-cell dimensions are given in Table 2. Final atomic positions, selected interatomic distances, and refined site occupancies are listed in Tables 3, 4, and 5, respectively ${ }^{1}$. Typical observed, calculated, and difference X-ray powder diffraction patterns for an amphibole of intermediate composition are shown in Figure 3.

The raw infrared spectra and band nomenclature are shown in Figure 4, and the fitted spectra are shown in Figure 5. Band positions, widths, and relative intensities $\left(I / /^{\circ \circ}\right)$ are given in Table 6 . The spectrum of end-member richterite shows an intense band centered at $3730 \mathrm{~cm}^{-1}$, assigned to an $\mathrm{MgMgMg}-\mathrm{OH} \rightarrow \mathrm{Na}$ configuration and designated the A band, and a minor band at $3675 \mathrm{~cm}^{-1}$ resulting from the presence of some vacant A sites in the

A copy of Tables 3 and 4 may be ordered as Document AM-97-634 from the Business Office, Mineralogical Society of America, 1015 Eighteenth Street NW, Suite 601, Washington, DC 20036, U.S.A. Please remit $\$ 5.00$ in advance for the microfiche. 
TABLE 2. Cell parameters of synthetic (nickel, magnesium, cobalt)-richterite

\begin{tabular}{lccccccc}
\hline \hline & $\mathrm{Mg}(100)$ & $\mathrm{Ni}(20)$ & $\mathrm{Ni}(40)$ & $\mathrm{Ni}(60)$ & $\mathrm{Ni}(80)$ & $\mathrm{Ni}(100)$ & $\mathrm{Co}(20)$ \\
\hline$a(\AA ̊)$ & $9.9076(6)$ & $9.9073(6)$ & $9.9024(6)$ & $9.8956(6)$ & $9.8886(6)$ & $9.890(1)$ & $9.9180(6)$ \\
$b(\AA)$ & $17.988(1)$ & $17.978(1)$ & $17.965(1)$ & $17.948(1)$ & $17.933(1)$ & $17.925(2)$ & $17.999(1)$ \\
$c(\AA)$ & $5.2706(4)$ & $5.2669(3)$ & $5.2603(4)$ & $5.2567(3)$ & $5.2525(3)$ & $5.2527(6)$ & $5.2714(3)$ \\
$\beta\left({ }^{\circ}\right)$ & $104.252(4)$ & $104.303(4)$ & $104.361(4)$ & $104.413(4)$ & $104.461(4)$ & $104.501(8)$ & $104.246(4)$ \\
$V\left(\AA^{3}\right)$ & 910.41 & 909.03 & 906.55 & 904.24 & 901.93 & 901.52 & 912.08 \\
\hline
\end{tabular}

amphibole (band $\mathrm{A}^{*}$ in Table 6). The spectra of the intermediate amphibole solid solutions show four relatively intense bands designated A, B, C, and D, and these bands are due to the local $\mathrm{Ni}-\mathrm{Mg}$ and $\mathrm{Mg}$-Co configurations around the $\mathrm{OH}$ site. The spectra of the intermediate-composition amphiboles (Fig. 5) also show that the $\mathrm{A}^{*}$ band is also associated with a triplet of additional bands. These bands are designated $\mathrm{B}^{*}, \mathrm{C}^{*}$, and $\mathrm{D}^{*}$. The assignment of bands to specific local configurations is shown in Table 7.

\section{Discussion}

\section{Cell dimensions}

The variation in cell dimensions is shown in Figures 6 and 7 , together with the data for synthetic (nickel, magnesium, cobalt)-potassium-richterite (Della Ventura et al. 1993b) and the synthetic richterite-ferro-richterite series (Charles 1974). For (magnesium, iron)-richterite, Charles (1974) gave several sets of cell dimensions for each composition. Virgo (1972) showed by Mössbauer spectroscopy that these specific synthetic amphiboles all contain some $\mathrm{Fe}^{3+}$. Incorporation of $\mathrm{Fe}^{3+}$ into the richterite structure reduces the cell dimensions below those of ideal $\mathrm{Fe}^{3+}$-free richterite. Consequently, we used the cell dimensions of Charles (1974) with the largest cell volume for each nominal composition, presuming that these am-

TABLE 5. Refined site populations of synthetic (nickel, magnesium, cobalt)-richterite

\begin{tabular}{lcclllc}
\hline \hline & $\mathrm{Mg}(100)$ & $\mathrm{Ni}(20)$ & $\mathrm{Ni}(40)$ & $\mathrm{Ni}(60)$ & $\mathrm{Ni}(80)$ & $\mathrm{Ni}(100)$ \\
\hline $\mathrm{M} 1 \mathrm{Mg}$ & $1.96(2)$ & $1.54(2)$ & $1.02(4)$ & $0.60(4)$ & $0.24(4)$ & - \\
$\mathrm{M} 1 \mathrm{Ni}$ & - & $0.46(2)$ & $0.98(4)$ & $1.40(4)$ & $1.76(4)$ & $2.00(2)$ \\
M2 Mg & $2.08(2)$ & $1.78(2)$ & $1.46(4)$ & $1.10(4)$ & $0.64(4)$ & - \\
M2 Ni & - & $0.22(2)$ & $0.54(4)$ & $0.90(4)$ & $1.36(4)$ & $1.98(2)$ \\
M3 Mg & $1.00(1)$ & $0.70(1)$ & $0.48(1)$ & $0.25(2)$ & $0.13(1)$ & - \\
M3 Ni & - & $0.30(1)$ & $0.52(1)$ & $0.75(2)$ & $0.87(1)$ & $0.98(2)$ \\
$\mathrm{Ni}$ (nom) & - & 1.00 & 2.00 & 3.00 & 4.00 & 5.00 \\
$\mathrm{Ni}$ (obs) & - & $0.98(2)$ & $2.04(4)$ & $3.05(5)$ & $4.19(4)$ & $4.96(3)$ \\
M4 Ca & $1.05(1)$ & $1.09(1)$ & $1.12(2)$ & $1.07(2)$ & - & $1.02(2)$ \\
M4 Na & $0.95(1)$ & $0.91(1)$ & $0.88(2)$ & $0.93(2)$ & - & $0.98(2)$ \\
$\mathrm{A} \mathrm{Na}$ & $0.95(1)$ & $0.91(1)$ & $0.88(2)$ & $0.93(2)$ & $>1$ & $0.98(2)$ \\
& & $\mathrm{Co}(20)$ & $\mathrm{Co}(40)$ & $\mathrm{Co}(60)$ & $\mathrm{Co}(80)$ & $\mathrm{Co}(100)$ \\
\hline $\mathrm{M} 1 \mathrm{Mg}$ & & $1.54(2)$ & $1.08(4)$ & $0.74(4)$ & $0.36(4)$ & - \\
M1 Co & & $0.46(2)$ & $0.92(4)$ & $1.26(4)$ & $1.64(4)$ & $1.90(4)$ \\
M2 Mg & & $1.60(4)$ & $1.24(4)$ & $0.88(4)$ & $0.56(4)$ & - \\
M2 Co & & $0.40(4)$ & $0.76(4)$ & $1.12(4)$ & $1.44(4)$ & $1.86(4)$ \\
M3 Mg & & $0.77(1)$ & $0.53(1)$ & $0.34(1)$ & $0.21(2)$ & - \\
M3 Co & & $0.23(1)$ & $0.47(1)$ & $0.66(1)$ & $0.79(2)$ & $0.96(1)$ \\
Co (nom) & & 1.00 & 2.00 & 3.00 & 4.00 & 5.00 \\
Co (obs) & & $1.09(3)$ & $2.15(4)$ & $3.04(4)$ & $3.87(5)$ & $4.72(4)$ \\
M4 Ca & & $1.10(1)$ & $1.11(1)$ & $1.11(2)$ & $1.01(2)$ & $0.95(3)$ \\
M4 Na & & $0.90(1)$ & $0.89(1)$ & $0.89(2)$ & $0.99(2)$ & $1.05(3)$ \\
A Na & & $0.91(1)$ & $0.88(2)$ & $0.93(2)$ & $>1$ & $0.98(2)$ \\
\hline
\end{tabular}

phiboles will have the lowest content of $\mathrm{Fe}^{3+}$. In each series, the cell volume increases regularly (Fig. 6) in response to the increasing size of the constituent cations ${ }^{\left[{ }^{[6]}\right.} r\left(\mathrm{Ni}^{2+}\right)=0.690 \AA,{ }^{[6]} r(\mathrm{Mg})=0.720 \AA,{ }^{[6]} r\left(\mathrm{Co}^{2+}\right)=$ $0.745 \AA,{ }^{[6]} r\left(\mathrm{Fe}^{2+}\right)=0.780 \AA$; Shannon 1976]. The one exception to this is the $\mathrm{Ni}(100)$ sample, which has a cell volume similar to that of the $\mathrm{Ni}(80)$ sample. We recollected the diffraction data on this sample and obtained the same result. We then recollected the data on the complete (nickel, magnesium)-richterite series and obtained the same result. Next, we resynthesized the (nickel, magnesium)-richterite samples, collected the diffraction data, and obtained the same result. Thus, we conclude that $\mathrm{Ni}(100)$ has about the same cell volume as $\mathrm{Ni}(80)$.

The relative variation of individual cell dimensions differs significantly between the two series. Along the $\mathrm{Ni}-\mathrm{Mg}$ join (Fig. 7), $a, b$, and $c$ increase with increasing cation size, but the beta angle decreases markedly. Significantly different behavior is observed in the Mg-Co series. The $a$ and $b$ dimensions of the Mg-Co series increase more strongly with increasing constitutent-cation radius than those of the $\mathrm{Ni}-\mathrm{Mg}$ series. This is also the case in the $a$ dimension for the Mg-Fe series, but the rate of increase is not as great as in the Mg-Co series. The $c$ dimension shows the reverse behavior. The rate of increase of $c$ as a function of constituent-cation radius is smaller than in the Mg-Co series relative to that in the $\mathrm{Ni}-\mathrm{Mg}$ series, whereas the $\mathrm{Mg}$-Fe series is colinear with the Ni-Mg series (Fig. 7). The beta angle decreases from nickel-richterite to richterite but increases slightly to cobalt-richterite, whereas it continues to decrease from richterite to ferro-richterite.

The cell volumes for the $\mathrm{K}$ series are greater than those of the analogous $\mathrm{Na}$ series (Fig. 6), in accord with the larger size of $\mathrm{K}$ relative to $\mathrm{Na}$, but the general trends are parallel. Careful inspection of Figure 6 shows that the trends for the $\mathrm{K}$ and $\mathrm{Na}$ amphiboles are slightly nonlinear, with a break at ${ }^{[6]} r=0.72 \AA(\mathrm{Mg})$. Although the behaviors of the $\mathrm{K}$ and $\mathrm{Na}$ analogs are generally similar, some interesting differences are apparent. For $a$, the trends are virtually identical but displaced by approximately $0.14 \AA$. The values for $b$ for the $\mathrm{K}$ and $\mathrm{Na}$ analogs are very similar (Fig. 7), in accord with the conclusion of Colville et al. (1966) that the $b$ dimension in amphiboles is controlled primarily by the aggregate radius of the cations occupying the M2 site. The variation in the $c$ dimension (Fig. 7) is very interesting. In the Ni-Mg series, $c$ increases linearly with constituent-cation radius for both the $\mathrm{K}$ and the $\mathrm{Na}$ amphiboles, the displacement between the 
TABLE 2. Extended

\begin{tabular}{cccc}
\hline \hline Co(40) & Co(60) & \multicolumn{1}{c}{ Co(80) } & Co(100) \\
\hline $9.9312(6)$ & $9.9436(5)$ & $9.9568(6)$ & $9.9724(7)$ \\
$18.015(1)$ & $18.029(1)$ & $18.049(1)$ & $18.069(1)$ \\
$5.2731(3)$ & $5.2740(3)$ & $5.2742(3)$ & $5.2775(3)$ \\
$104.245(1)$ & $104.259(4)$ & $104.259(4)$ & $104.261(5)$ \\
914.41 & 916.36 & 918.00 & 921.65 \\
\hline
\end{tabular}

trends being 0.03-0.04 $\AA$. At the end-member Mg composition, there is a sharp discontinuity in each trend; in (magnesium, cobalt)-richterite, $c$ continues to increase but at a lower rate, whereas in (magnesium, cobalt)-potassium-richterite, $c$ actually decreases slightly with increasing Co content. In the $\mathrm{K}$ and $\mathrm{Na}$ amphiboles, there is a marked break in the variation in $c$ between the $\mathrm{Ni}-\mathrm{Mg}$ series and the $\mathrm{Mg}-\mathrm{Co}$ series, whereas in the $\mathrm{Na}$ amphiboles, the $c$ values for the $\mathrm{Mg}-\mathrm{Fe}$ series are approximately colinear with those of the Ni-Mg series. The behavior of the beta values is very similar (Fig. 7), with both (magnesium, cobalt)-potassium-richterite and (magnesium, cobalt)-richterite deviating markedly from the linear (or near-linear) trends for (nickel, magnesium)-potassiumrichterite, (nickel, magnesium)-richterite, and (magnesium, iron)-richterite.

The variation in cell dimensions as a function of the composition of the octahedral strip is affected by (1) the cation size and (2) the electronic configuration of the constituent cations. The almost linear increase in cell volume as a function of increasing cation size in the octahedral strip (Fig. 6) shows that cation size has its usual scalar effect, with slight nonlinearity at the $\mathrm{Ni}$ end of the series. However, the unusual discontinuities in individual cell dimensions and the markedly different behavior of the different transition-metal compositions indicate that electronic configuration is also a major factor, as discussed by Della Ventura et al. (1993b).

\section{Bulk composition}

The refined site occupancies of synthetic (nickel, magnesium, cobalt)-richterite are given in Table 5. Raudsepp et al. (1990) showed that the Rietveld method gives quite accurate site occupancies and bulk compositions if reasonable values are used for the isotropic displacement factors. Comparison of the refined and nominal $\mathrm{Ni}-\mathrm{Mg}$ and Mg-Co compositions (Fig. 8) shows generally good agreement, in accord with the fact that there were no significant amounts of additional phases found by X-ray diffraction or SEM, although there is a significant difference for the most Co-rich amphiboles (Table 5).

\section{Site occupancies: Long-range and short-range order}

Both $\mathrm{Ni}$ and Co preferentially enter the $\mathrm{OH}$-coordinated M1 and M3 sites for intermediate compositions (Table 5), whereas $\mathrm{Mg}$ prefers M2. The Ni and Co distributions over M1 and M3 are similar, with a slight preference for M3 over M1; this is not significant in terms of the assigned standard deviation but is systematic across the se-
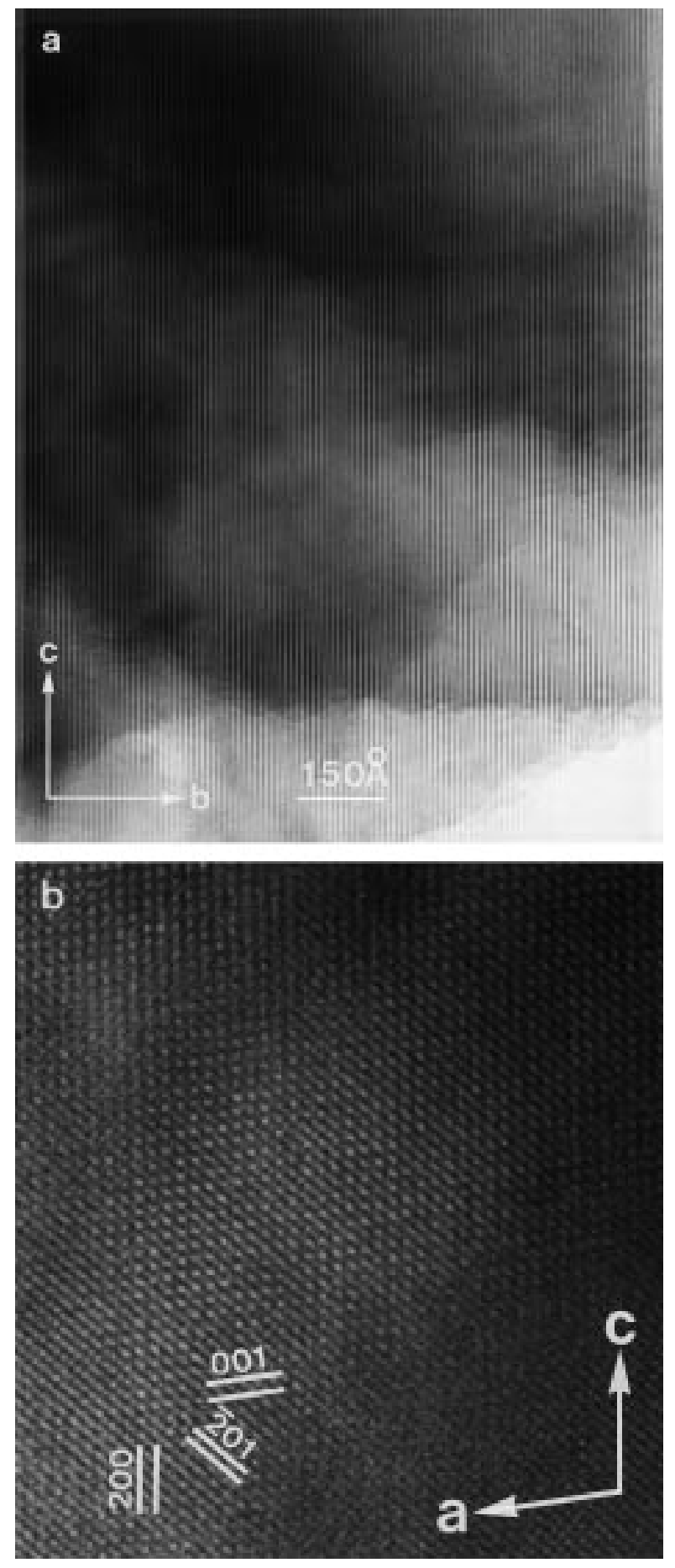

Figure 2. HRTEM images of synthetic (nickel, magnesium, cobalt)-richterite: (a) a (100) view of end-member nickel-richterite, showing an homogeneous defect-free microstructure consisting of uninterrupted double chains defined by $8.9 \AA$ (020) fringes, (b) A (010) view of richterite $\mathrm{Co}_{60} \mathrm{Mg}_{40}$, showing a monotonous monoclinic stacking sequence defined by a $4.8 \AA$ periodicity of (200) lattice fringes. No chain-arrangement faults were observed in any of the amphiboles studied; the patchy contrast seen in b reflects slight thickness variations resulting from differential beam damage. 


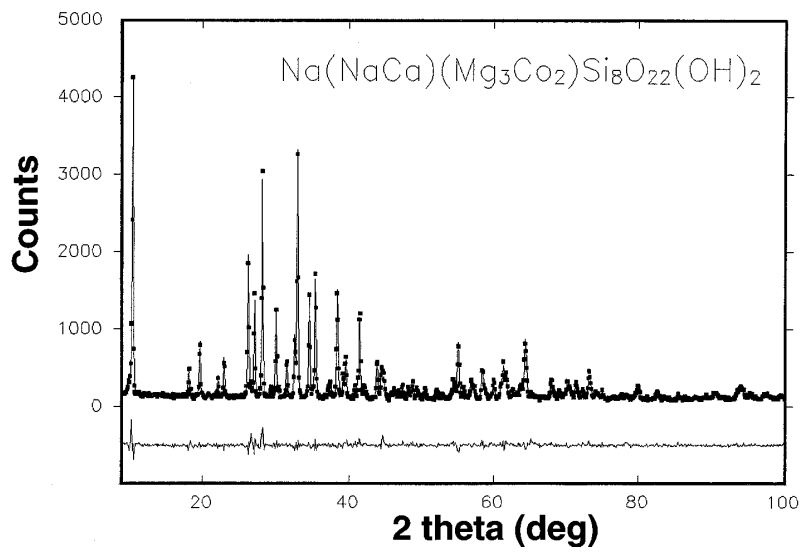

Figure 3. Observed (top line), calculated (dots), and difference (bottom line) X-ray powder diffraction pattern for $\mathrm{Na}(\mathrm{NaCa})\left(\mathrm{Mg}_{3} \mathrm{Co}_{2}\right) \mathrm{Si}_{8} \mathrm{O}_{22}(\mathrm{OH})_{2}$.

ries. The relation between $\mathrm{Ni}$ and $\mathrm{Co}$ at $\mathrm{M} 1,3$ and $\mathrm{M} 2$ is shown in Figure 9. The data of Table 5 allow calculation of the partition coefficients for $\mathrm{Ni}$ and Co over the M1,3 and M2 sites, defined as

$$
K_{\mathrm{d} 2+}^{\mathrm{M} 2+}\left(\mathrm{M}^{2+} / \mathrm{Mg}\right)_{\mathrm{M} 1,3} /\left(\mathrm{M}^{2+} / \mathrm{Mg}\right)_{\mathrm{M} 2},
$$$$
\text { with } \mathrm{M}^{2+}=\mathrm{Ni}^{2+} \text { or } \mathrm{Co}^{2+} \text {. }
$$

For the (nickel, magnesium)-richterite series; $K_{\mathrm{d}}^{\mathrm{Ni}}=2.98$ \pm 0.37; for the (magnesium, cobalt)-richterite series; $K_{\mathrm{d}}^{\mathrm{Co}}=1.34 \pm 0.31$. The corresponding values for the analogous potassium-richterite series are $K_{\mathrm{d}}^{\mathrm{Ni}}=4.26 \pm$ 0.56 and $K_{\mathrm{d}}^{\mathrm{Co}}=1.92 \pm 0.29$.

The $K_{\mathrm{d}}$ values indicate that electronic structure has a major effect on long-range ordering (LRO) of cations in the amphibole structure. $\mathrm{Ni}^{2+}$ is smaller than $\mathrm{Mg}$, whereas $\mathrm{Co}^{2+}$ is larger than $\mathrm{Mg}$, and if LRO of cations were controlled solely by cation size (for a specific structure type),

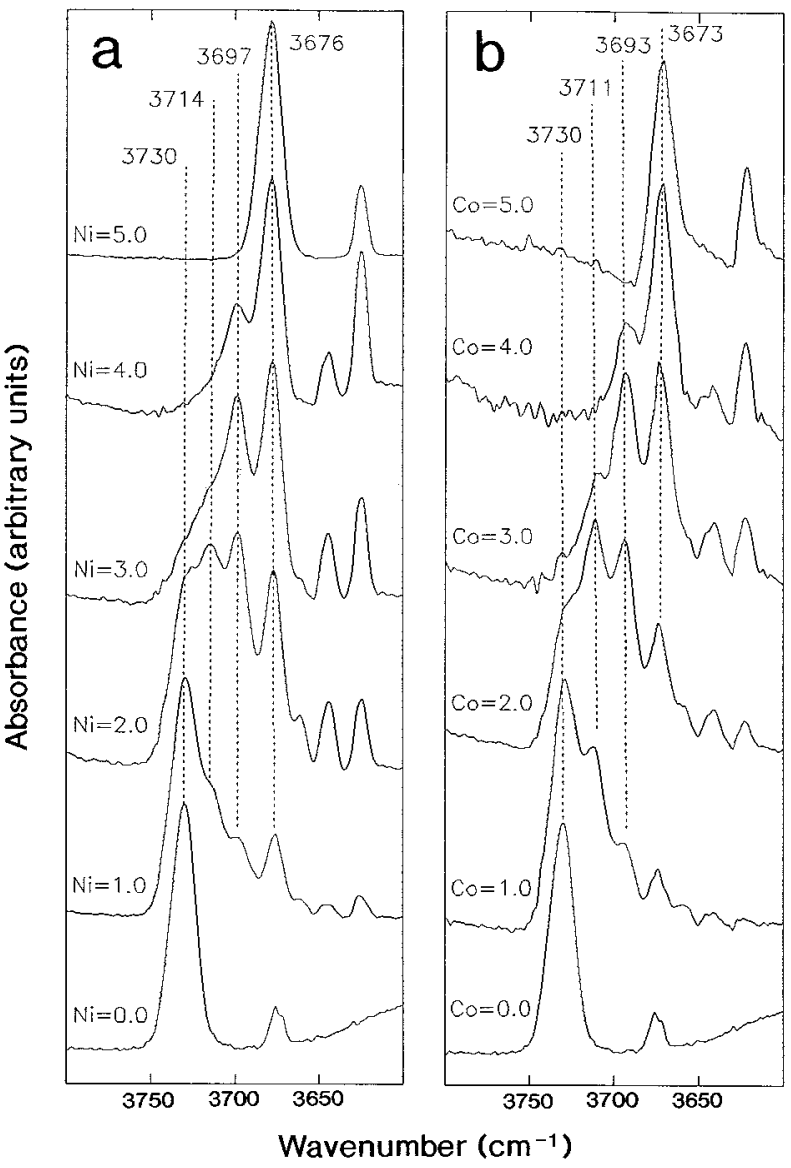

Figure 4. FTIR spectra in the OH-stretching region for amphiboles synthesized along (a) the (magnesium, nickel)-richterite join and (b) the (magnesium, cobalt)-richterite join.

TABLE 6. Refined positions $\left(\mathrm{cm}^{-1}\right)$, widths $\left(\mathrm{cm}^{-1}\right)$, and intensities of (nickel, magnesium)- and (magnesium, cobalt)-richterite

\begin{tabular}{|c|c|c|c|c|c|c|c|c|c|c|c|c|}
\hline & & $\mathrm{Ni}(0)$ & $\mathrm{Ni}(20)$ & $\mathrm{Ni}(40)$ & $\mathrm{Ni}(60)$ & $\mathrm{Ni}(80)$ & $\mathrm{Ni}(100)$ & $\mathrm{Co}(20)$ & $\mathrm{Co}(40)$ & $\mathrm{Co}(60)$ & $\mathrm{Co}(80)$ & $\mathrm{Co}(100)$ \\
\hline \multirow[t]{3}{*}{ A } & Position & 3730.7 & 3730.7 & 3729.4 & 3730.5 & 3729.8 & - & 3729.6 & 3729.0 & 3729.1 & 3730.2 & - \\
\hline & Width & 16.9 & 16.9 & 16.7 & 16.6 & 16.6 & - & 17.0 & 16.6 & 16.5 & 16.1 & - \\
\hline & Intensity & 0.92 & 0.468 & 0.217 & 0.084 & 0.017 & - & 0.462 & 0.194 & 0.040 & 0.000 & - \\
\hline \multirow[t]{3}{*}{ B } & Position & - & 3714.3 & 3713.7 & 3714.7 & 3713.6 & - & 3711.2 & 3711.4 & 3711.0 & 3711.0 & - \\
\hline & Width & - & 16.9 & 16.6 & 16.6 & 16.6 & - & 16.4 & 16.8 & 16.2 & 16.1 & - \\
\hline & Intensity & - & 0.222 & 0.231 & 0.160 & 0.062 & - & 0.306 & 0.320 & 0.161 & 0.032 & - \\
\hline \multirow[t]{3}{*}{ C } & Position & - & 3697.3 & 3697.5 & 3798.5 & 3698.7 & - & 3693.0 & 3693.2 & 3692.8 & 3692.1 & - \\
\hline & Width & - & 16.6 & 15.7 & 15.7 & 16.0 & - & 14.7 & 15.0 & 16.0 & 16.1 & - \\
\hline & Intensity & - & 0.134 & 0.241 & 0.288 & 0.223 & - & 0.122 & 0.259 & 0.339 & 0.238 & - \\
\hline \multirow[t]{3}{*}{ D } & Position & - & 3677.5 & 3677.7 & 3678.7 & 3678.9 & 3679.0 & 3671.3 & 3671.5 & 3671.7 & 3671.5 & 3671.5 \\
\hline & Width & - & 15.5 & 14.8 & 14.8 & 14.8 & 15.7 & 15.0 & 15.0 & 14.8 & 15.6 & 14.0 \\
\hline & Intensity & - & 0.089 & 0.171 & 0.291 & 0.442 & 0.86 & 0.037 & 0.112 & 0.285 & 0.495 & 0.78 \\
\hline \multirow[t]{3}{*}{$A^{*}$} & Position & 3674.8 & 3675.3 & 3674.9 & 3674.8 & 3674.8 & - & 3674.8 & 3675.2 & 3675.0 & 3675.0 & - \\
\hline & Width & 9.8 & 8.7 & 8.4 & 8.9 & 8.4 & - & 8.9 & 9.1 & 9.5 & 9.1 & - \\
\hline & Intensity & 0.08 & 0.037 & 0.025 & 0.033 & 0.024 & - & 0.036 & 0.036 & 0.031 & 0.043 & - \\
\hline \multirow[t]{3}{*}{$\mathrm{B}^{*}$} & Position & - & 3660.7 & 3660.9 & 3661.6 & 3660.4 & - & 3658.3 & 3657.2 & 3655.8 & 3657.3 & - \\
\hline & Width & - & 8.1 & 8.0 & 8.4 & 8.4 & - & 8.7 & 9.4 & 9.3 & 9.4 & - \\
\hline & Intensity & - & 0.015 & 0.026 & 0.011 & 0.005 & - & 0.018 & 0.026 & 0.033 & 0.029 & - \\
\hline \multirow[t]{3}{*}{$C^{*}$} & Position & - & 3645.2 & 3644.4 & 3644.7 & 3644.7 & - & 3642.3 & 3641.2 & 3641.8 & 3641.0 & - \\
\hline & Width & - & 8.6 & 8.7 & 8.1 & 7.7 & - & 8.9 & 9.3 & 9.0 & 9.0 & - \\
\hline & Intensity & - & 0.014 & 0.044 & 0.052 & 0.050 & - & 0.013 & 0.034 & 0.058 & 0.049 & - \\
\hline \multirow[t]{3}{*}{$D^{*}$} & Position & - & 3625.0 & 3624.6 & 3624.7 & 3624.7 & 3624.8 & 3622.8 & 3622.5 & 3622.4 & 3622.4 & 3621.8 \\
\hline & Width & - & 8.0 & 8.4 & 8.1 & 8.4 & 8.0 & 7.9 & 8.9 & 8.5 & 8.5 & 8.4 \\
\hline & Intensity & - & 0.022 & 0.044 & 0.081 & 0.176 & 0.14 & 0.005 & 0.020 & 0.054 & 0.115 & 0.22 \\
\hline
\end{tabular}


then $K_{\mathrm{d}}$ for $\mathrm{Ni}^{2+}-\mathrm{Mg}$ ordering should lie on one side of 1.0 and $K_{\mathrm{d}}$ for $\mathrm{Co}^{2+}-\mathrm{Mg}$ ordering should lie on the other side of 1.0. The fact that $K_{\mathrm{d}}$ values for both $\mathrm{Ni}^{2+}$ and $\mathrm{Co}^{2+}$ are $>1.0$ indicates that the primary factor controlling LRO is not cation size in this case. The other obvious factor involved is the electronic structure of the transition metal (Della Ventura et al. 1993b). In the 1960s and 1970 s, there was a considerable amount of work on the effects of crystal-field stabilization energies on the ordering of transition metals in minerals. However, the arguments were qualitative or semiquantitative in nature and not very definitive in terms of explaining cation ordering. Recent results on synthetic amphiboles and pyroxenes suggest that electronic structure plays an important role in affecting both cation ordering and variation in cell dimensions in these structures, indicating that a more quantitative approach to those aspects of electronic structure of minerals is warranted.

Hawthorne et al. (1996) showed that it is possible to get information on short-range ordering (SRO) of cations over the M1 and M3 sites in amphibole from the fine structures in the principal $\mathrm{OH}$-stretching spectrum. Della Ventura et al. (1996) showed that there is slight preferential SRO in synthetic (nickel, magnesium, cobalt)-potassium-richterite, with $\mathrm{MgMgMg}$ and possible $\mathrm{NiNiNi}$ (and $\mathrm{CoCoCo}$ ) clusters being more common than expected for random mixing. In (nickel, magnesium, cobalt)richterite, the $A^{*}-D^{*}$ bands are much more relatively intense than in (nickel, magnesium, cobalt)-potassiumrichterite, preventing a convincing examination of shortrange order-disorder in (nickel, magnesium, cobalt)richterite.

\section{Bond Lengths}

Previous work (Raudsepp et al. 1987a, 1987b) on the structural refinements of amphiboles by the Rietveld method noted the low accuracy of the resulting individual bond lengths because of pseudosymmetry in the amphibole structure. However, the grand $\langle\mathrm{M}-\mathrm{O}\rangle$ bond lengths are more well behaved (Della Ventura et al. 1993b). The grand $\langle\mathrm{M}-\mathrm{O}\rangle$ bond lengths of the (nickel, magnesium)and (magnesium, cobalt)-richterite series (Fig. 10) do show an increase with increasing constituent-cation radius. Fitting the variation with a single straight line gives a slope of 0.89 (Fig. 10), somewhat less than the value of $\sim 1$ observed for natural amphiboles (Hawthorne 1983b). A much closer fit to the data is obtained for a bilinear model with a break at $0.72 \AA(\mathrm{Mg})$ (broken line in Fig. 10), although the slope of the segment with $\langle r\rangle\rangle$ $0.72 \AA$ is significantly steeper than the analogous line for natural amphiboles. The synthetic (nickel, magnesium, cobalt)-potassium-richterite series (Della Ventura et al. 1993b) and the synthetic diopside series containing (Ni,Mg,Co, and $\mathrm{Fe}^{2+}$ ) (Raudsepp et al. 1990) also show this feature, whereas synthetic olivine (Raudsepp et al. 1990, Fig. 7) does not. Raudsepp et al. (1990) concluded that this nonlinearity is an intrinsic feature of the calcic pyroxene structure and results because the structure is

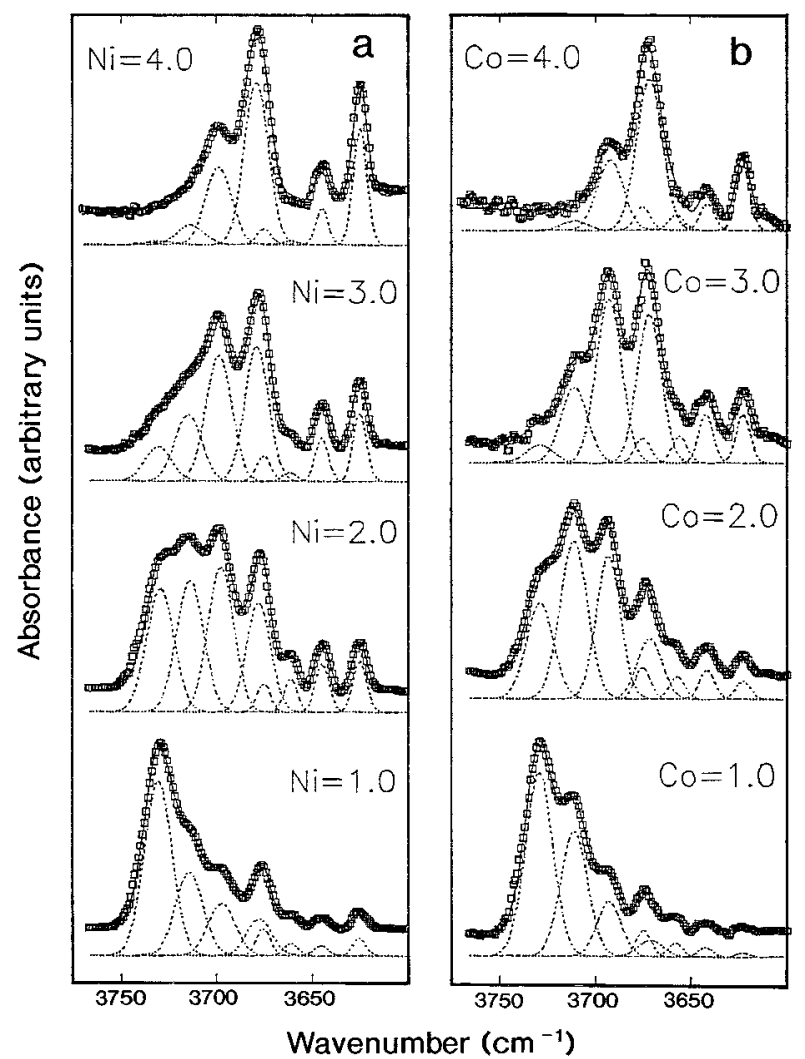

Figure 5. Resolved spectra for the intermediate amphiboles synthesized along (a) the (magnesium, nickel)-richterite join and (b) the (magnesium, cobalt)-richterite join. Resolved bands (dotted lines) are vertically displaced for clarity; observed intensities are shown by the open squares, and the line through the observed intensities is the envelope of the sum of the fitted component bands.

TABLE 7. Possible local arrangements around the $\mathrm{O} 3$ site in amphiboles with $\left(\mathrm{Mg} \mathrm{M}^{2+}\right)$ at $\mathrm{M} 1$ and $\mathrm{M} 3$

\begin{tabular}{|c|c|c|c|c|c|c|}
\hline & M1 & M1 & M3 & Band $^{*}$ & $\begin{array}{c}\text { Band } \\
(\mathrm{A}=\mathrm{Na})^{\star *}\end{array}$ & $\begin{array}{c}\text { Band } \\
(A=\square)\end{array}$ \\
\hline 1 & $\mathrm{Mg}$ & $\mathrm{Mg}$ & $\mathrm{Mg}$ & A & $A$ & $A^{*}$ \\
\hline 2 & $\mathrm{Mg}$ & $\mathrm{Mg}$ & $\mathrm{M}^{2+}$ & $B^{\prime}$ & & \\
\hline 3 & $\mathrm{M}^{2+}$ & $\mathrm{Mg}$ & $\mathrm{Mg}$ & $\mathrm{B}^{\prime \prime}$ & $B$ & $B^{*}$ \\
\hline 4 & $\mathrm{Mg}$ & $\mathrm{M}^{2+}$ & $\mathrm{Mg}$ & $\mathrm{B}^{\prime \prime}$ & & \\
\hline 5 & $\mathrm{M}^{2+}$ & $\mathrm{M}^{2+}$ & $\mathrm{Mg}$ & $C^{\prime}$ & & \\
\hline 6 & $\mathrm{M}^{2+}$ & $\mathrm{Mg}$ & $\mathrm{M}^{2+}$ & $\mathrm{C}^{\prime \prime}$ & C & $C^{*}$ \\
\hline 7 & $\mathrm{Mg}$ & $\mathrm{M}^{2+}$ & $\mathrm{M}^{2+}$ & $\mathrm{C}^{\prime \prime}$ & & \\
\hline 8 & $\mathrm{M}^{2+}$ & $\mathrm{M}^{2+}$ & $\mathrm{M}^{2+}$ & D & D & $D^{*}$ \\
\hline
\end{tabular}

* Ideal band structure; 3 and 4 are symmetrically equivalent and produce only one band: $\mathrm{B}^{\prime \prime}$; similarly, 6 and 7 are symmetrically equivalent and produce only one band: $\mathrm{C}^{\prime \prime}$.

** Band structure usually observed; 2 and $(3+4)$ are pseudosymmetrically degenerate, and only one band $(B)$ is observed experimentally; similarly, 5 and $(6+7)$ are pseudosymmetrically degenerate, and only one band $(C)$ is observed experimentally. 


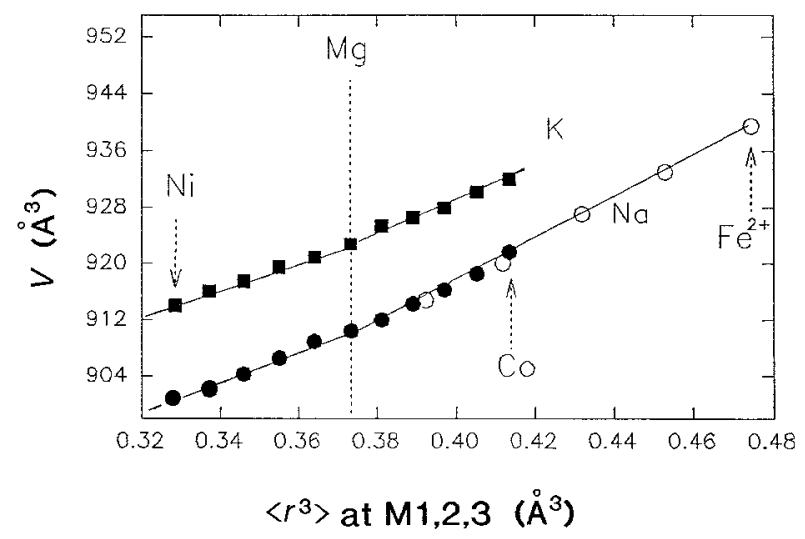

Figure 6. Variation of the cell volume of synthetic (nickel, magnesium, cobalt)-richterite (solid circles) and synthetic (nickel, magnesium, cobalt)-potassium-richterite (squares) as a function of the cube of the aggregate cation radius at the M1,2,3 sites; open circles represent synthetic $\left(\mathrm{Mg}, \mathrm{Fe}^{2+}\right)$-richterite (from Charles 1974).

nearing its lower limit of stability with regard to the incorporation of small divalent cations at the M1 site. The similarity between pyroxene and amphibole suggests that these structures might behave in a similar fashion; the results of the present work show this to be the case.

\section{Variation in molar absorptivity with frequency}

Strens (1966), Burns and Strens (1966), and Law (1976) showed that the relative intensities of the A, B, C, and $\mathrm{D}$ bands in the principal $\mathrm{OH}$-stretching spectra of amphiboles are related to cation ordering over the M1 and M3 sites. This approach assumed implicitly that the molar absorptivity is the same for each of these bands (i.e., the transition moment is the same for all local cation configurations in the structure). In a polarized singlecrystal study of amphiboles, Skogby and Rossman (1991) showed that the integrated molar absorptivity of the total envelope of the principal $\mathrm{OH}$-stretching bands increases with decreasing mean stretching frequency. Similar qualitative molar-absorptivity-frequency relations are also observed in polarized single-crystal spectra of vesuvianite (Groat et al. 1995). Burns and Hawthorne (1994) showed the analogous relation for normalized single $\mathrm{OH}$-stretching-band intensities in powder infrared spectra of borate minerals. Thus, the implicit assumption in previous work on powder spectra of amphiboles, that there is no variation in molar absorptivity with frequency, seems invalid. We must experimentally characterize this relation if we wish to quantitatively relate the intensities of the $\mathrm{OH}$ stretching bands to cation ordering in amphiboles.

Hawthorne et al. (1996) reexamined the problem of relating the binary site occupancies $x[=\mathrm{Mg} /(\mathrm{Mg}+$ $\left.\left.\mathrm{M}^{2+}\right)\right]$ and $y\left[=\mathrm{M}^{2+} /\left(\mathrm{Mg}+\mathrm{M}^{2+}\right)\right]$ at the $\mathrm{M} 1$ and $\mathrm{M} 3$ sites in the amphibole structure to the observed relative intensities, $I_{\mathrm{o}}$, of the component bands in the principal $\mathrm{OH}$-stretching spectrum. They showed that, provided there is no variation in molar absorptivity with band fre-

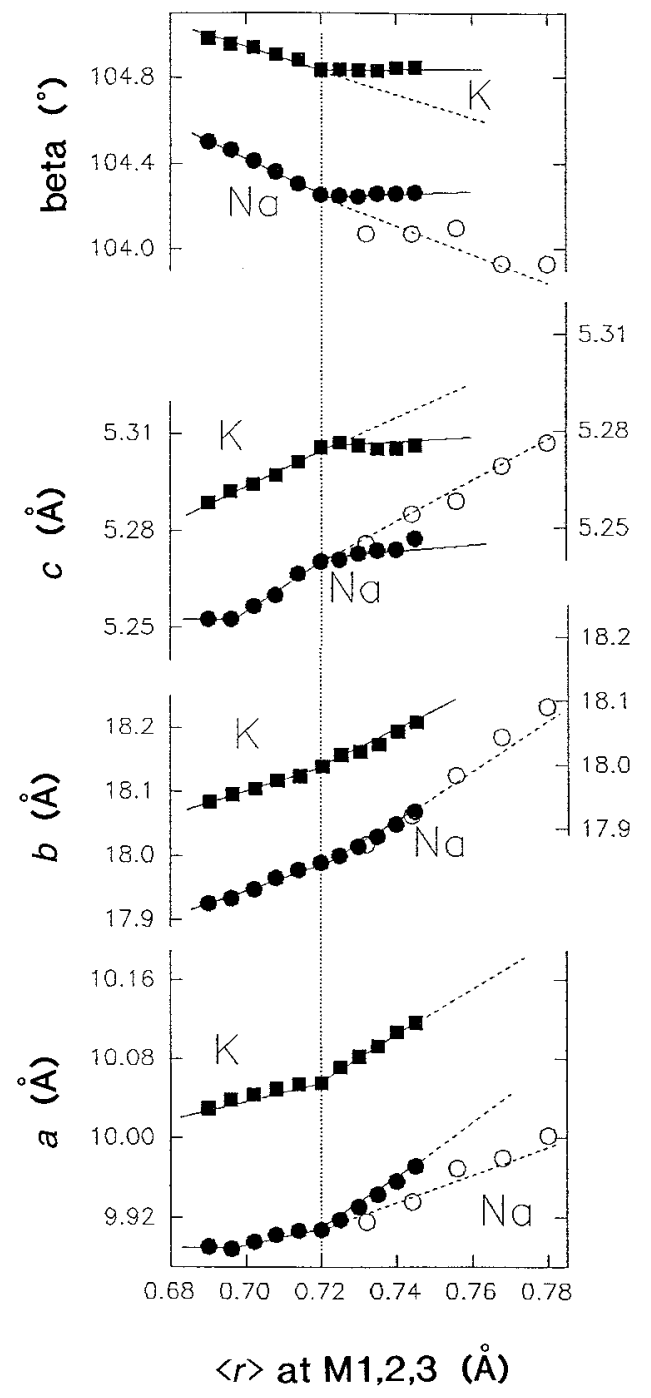

Figure 7. Variation in cell parameters of synthetic (nickel, magnesium, cobalt)-richterite, synthetic (nickel, magnesium, cobalt)-potassium-richterite, and synthetic $\left(\mathrm{Mg}, \mathrm{Fe}^{2+}\right)$-richterite as a function of the aggregate cation radius at the M1,2,3 sites. The dashed lines show either extrapolations of the linear fit to the (nickel, magnesium)-richterite and (nickel, magnesium)-potassium-richterite data or fits to the (magnesium, iron)-richterite data that are constrained to go through the values for end-member richterite.

quency within a single sample, the original equations of Burns and Strens (1966),

$$
\begin{aligned}
\mathrm{Mg}_{\mathrm{M} 1,3} & =3 I_{\mathrm{o}}^{\mathrm{A}}+2 I_{\mathrm{o}}^{\mathrm{B}}+I_{\mathrm{o}}^{\mathrm{C}} \\
\mathrm{M}_{\mathrm{M} 1,3}^{2+} & =I_{\mathrm{o}}^{\mathrm{B}}+2 I_{\mathrm{o}}^{\mathrm{C}}+3 I_{\mathrm{o}}^{\mathrm{D}}
\end{aligned}
$$

are correct. Della Ventura et al. (1996) showed that Equation 1 correctly predicts the $\mathrm{Mg}$ and $\mathrm{M}^{2+}$ contents of the M1,3 sites in (magnesium, nickel)- and (magnesium, cobalt)-potassium-richterite, i.e., when the molar absorptivity of all four bands, A-D, are assumed to be the same. Because this result apparently contradicts the work of 

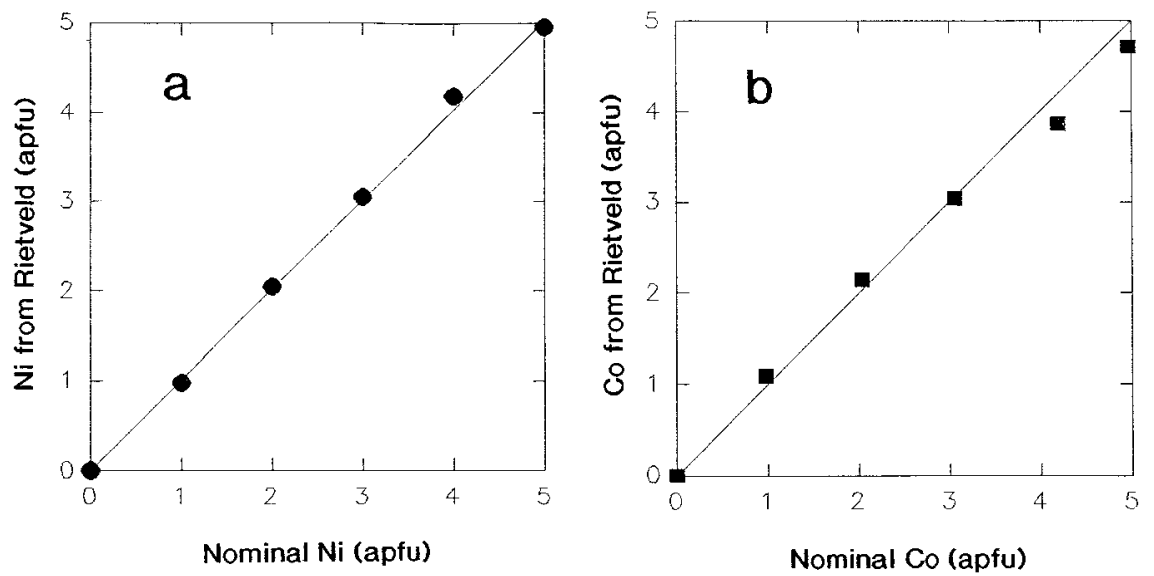

Figure 8. Nominal vs. refined Ni and Co contents of synthetic (nickel, magnesium, cobalt)-richterite.

Skogby and Rossman (1991), and the issue is extremely important for the application of infrared spectroscopy in general to the characterization of cation ordering in minerals, we examine Equation 1 for the amphiboles of this study. The situation is complicated somewhat in the present case by the presence of the $\mathrm{A}^{*}-\mathrm{D}^{*}$ set of bands, which also represent $\mathrm{Mg}-\mathrm{M}^{2+}$ ordering over the M1,3 sites. There are two ways in which this problem can be handled: (1) by using the A-D set of bands only and (2) by summing the analogous bands $\mathrm{A}+\mathrm{A}^{*}, \mathrm{~B}+\mathrm{B}^{*}$, etc. We get the same result in either case and hence just show the first case. Figure 11 shows the $\mathrm{M}^{2+}$ content of M1,3 sites as derived from the Rietveld site populations and from the infrared band intensities by Equation 1. There is close correspondence between the two sets of values for both (magnesium, nickel)- and (magnesium, cobalt)richterite. This indicates that there is no significant variation in molar absorptivity with band frequency (energy) within a single powder spectrum. The latter condition is extremely important because it possibly accounts for the difference between the results of Skogby and Rossman (1991) and the results derived here and by Della Ventura et al. (1996). Skogby and Rossman (1991) measured the molar absorptivity (excluding the $\beta$ component) on oriented single crystals and were able to compare measurements for different samples. Here, we measured only the relative intensities of bands within a single sample. We cannot compare absolute intensities between samples, as did Skogby and Rossman (1991), because particle effects among samples are so variable (we confirmed this experimentally). In powder samples, one can compare intensities only within a single spectrum (i.e., for a single sample in which particle effects are the same). Thus, Skogby and Rossman (1991) recorded a difference in transition probability (by molar absorptivity) with frequency in different samples, whereas we recorded no difference in transition probability (by relative band-intensity correlation with bulk composition) with frequency within a single sample. We may account for this in the following manner. In the amphibole structure, adjacent M1M1M3-
OH-A configurations share two out of three cations, and it is not unreasonable to propose that there are cooperative interactions between adjacent configurations such that transitions are coupled. Such coupling could lead to equal transition probabilities for adjacent configurations, and the continuous nature of the M1M1M3-OH-A configurations throughout the amphibole structure could lead to the same transition probability for all these configurations. Such coupling would not, of course, occur between different samples, and hence different samples may show different transition probabilities (molar absorptivities) as a function of mean absorption frequency. This proposal seems to account satisfactorily for the apparently different results obtained by Skogby and Rossman (1991)

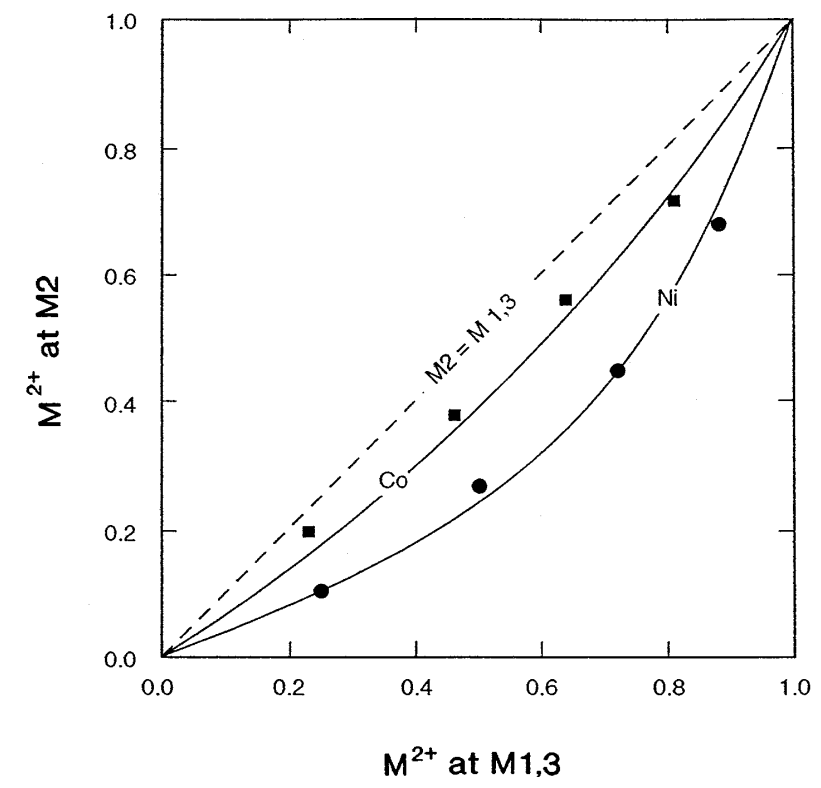

Figure 9. Relationship between the refined $\mathrm{Ni}-\mathrm{Mg}$ and $\mathrm{Co}-\mathrm{Mg}$ occupancies at the M1,3 and M2 sites in synthetic (nickel, magnesium, cobalt)-richterite. Dots $=\mathrm{Ni}-\mathrm{Mg}$ series, squares $=$ Mg-Co series. 


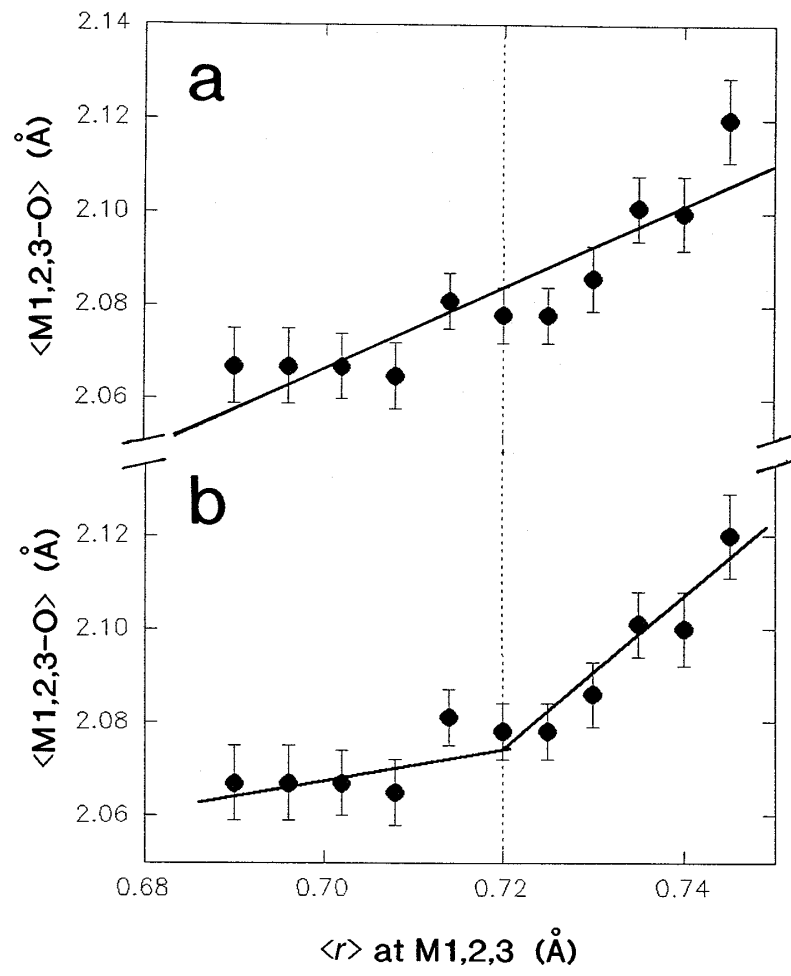

Figure 10. Variation of the grand $\langle\mathrm{M}-\mathrm{O}\rangle$ bond length for synthetic (nickel, magnesium, cobalt)-richterite as a function of the mean cation radius at M1,2,3; vertical bars represent the estimated standard deviations of (a) the linear fit to the data and (b) the bilinear fit to the data.

and by this study. Whether such coupling occurs in a specific mineral presumably depends on the details of its structure.

\section{The $\mathrm{A}^{*}, \mathrm{~B}^{*}, \mathrm{C}^{*}$, and $\mathrm{D}^{*}$ bands}

The $\mathrm{A}^{*}$ band has been assigned to an empty A-site configuration (Phillips and Rowbotham 1973; Della Ventura et al. 1991, 1993a; Robert et al. 1989). In accord with this assignment, the quartet of bands $\mathrm{A}, \mathrm{B}, \mathrm{C}$, and $\mathrm{D}$ is accompanied by a corresponding set of $\mathrm{A}^{*}, \mathrm{~B}^{*}, \mathrm{C}^{*}$, and $\mathrm{D}^{*}$ bands (Fig. 4). Comparison of the normalized relative intensities of all the bands, calculated as NORM $I_{\mathrm{o}}^{\mathrm{A}}$ $=I_{\mathrm{o}}^{\mathrm{A}} /\left(I_{\mathrm{o}}^{\mathrm{A}}+I_{\mathrm{o}}^{\mathrm{B}}+I_{\mathrm{o}}^{\mathrm{C}}+I_{\mathrm{o}}^{\mathrm{D}}\right)$ and ${ }^{N O R M} I_{\mathrm{o}^{*}}^{\mathrm{A}^{*}}=I_{\mathrm{o}^{*}}^{\mathrm{A}^{*}} /\left(I_{\mathrm{o}^{*}}^{\mathrm{A}^{*}}+I_{\mathrm{o}^{*}}^{\mathrm{B}^{*}}+\right.$ $\left.I_{\mathrm{o}^{*}}^{\mathrm{C}}+I_{\mathrm{o}}^{\mathrm{D}}\right)$, indicates that there are systematic differences in the ordering of the $\mathrm{C}$-group cations adjacent to filled $\mathrm{A}$ sites and adjacent to vacant A sites. This is not surprising. Comparison of the results obtained here with those of Della Ventura et al. (1993b, 1996) shows that the identity of the A cation ( $\mathrm{K}$ vs. Na) significantly affects the ordering of both $\mathrm{Ni}$ and Co over the M1,2,3 sites. Thus, it is reasonable to expect that $\square$ (vacancy) vs. Na would have an even greater effect on $\mathrm{Ni}$ and $\mathrm{Co}$ ordering.

\section{Acknowledgments}

We thank Bernard Evans and Roberta Oberti for their detailed comments on this manuscript. Part of this work was conducted during the stay

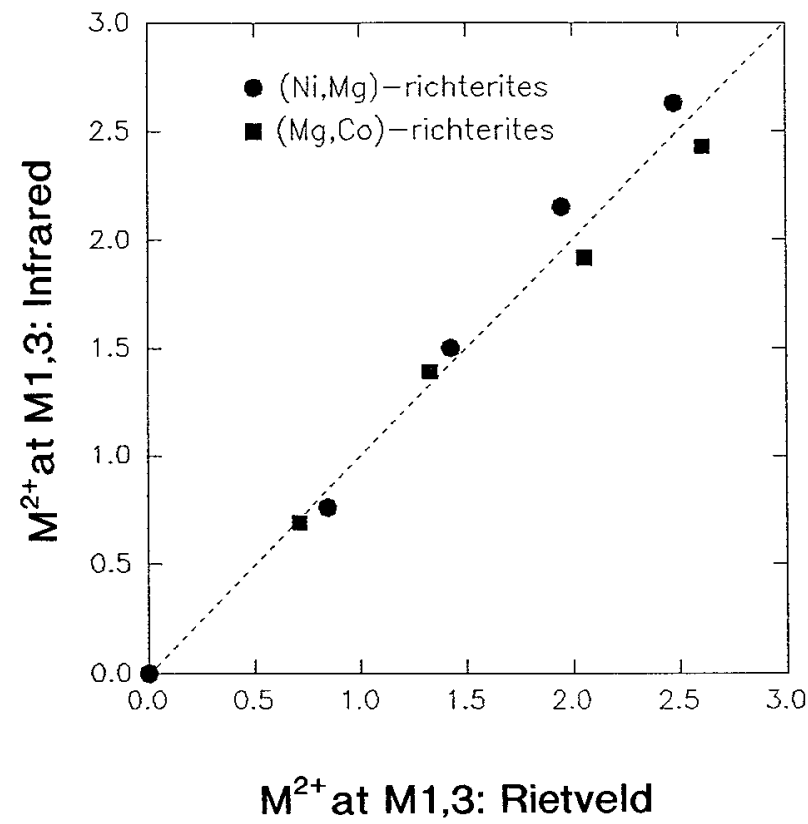

Figure 11. Variation in Ni (squares) and Co (circles) content of the M1,3 sites in (nickel, magnesium, cobalt)-richterite calculated from the IR band intensities vs. the corresponding values measured by Rietveld structure refinement assuming the same relative integrated molar absorptivity (1) for all bands in the spectrum.

of G.D.V. at the Department of Geological Sciences, University of Manitoba, Winnipeg, Manitoba, and was supported by a grant from the International Council for Canadian Studies. Financial assistance was provided by CNR grant 92.00774 .CT05 to G.D.V., and by the Natural Sciences and Engineering Research Council of Canada by Operating, Infrastructure, and Major Equipment grants to F.C.H.

\section{REFERENCES CITED}

Ahn, J.H., Cho, M., Jenkins, D.M., and Buseck, P.R. (1991) Structural defects in synthetic tremolitic amphiboles. American Mineralogist, 76, 1811-1823.

Boschmann, K., Burns, P.C., Hawthorne, F.C., Raudsepp, M., and Turnock, A.C. (1994) A-site disorder in synthetic fluor-edenite, a crystal structure study. Canadian Mineralogist, 32, 21-30.

Burns, R.G., and Strens, R.G.J. (1966) Infrared study of the hydroxyl bonds in clinoamphiboles. Science, 153, 890-892.

Burns, P.C., and Hawthorne, F.C. (1994) Structure and hydrogen bonding in preobrazhenskite, a complex heteropolyhedral borate. Canadian Mineralogist, 32, 387-396.

Cameron, M., Sueno, S., Papike, J.J., and Prewitt, C.T. (1983) High temperature crystal chemistry of $\mathrm{K}$ and $\mathrm{Na}$ fluor-richterites. American Mineralogist, 68, 924-943.

Charles, R.W. (1974) The physical properties of the Mg-Fe richterites. American Mineralogist, 59, 518-528.

Colville, P.A., Ernst, W.G., and Gilbert, M.C. (1966) Relationships between cell parameters and chemical compositions of monoclinic amphiboles. American Mineralogist, 51, 1727-1754.

Della Ventura, G. (1992) Recent developments in the synthesis and characterization of amphiboles. Synthesis and crystal-chemistry of richterites. Trends in Mineralogy, 1, 153-192.

Della Ventura, G., and Robert, J.-L. (1990) Synthesis, XRD and FTIR studies of strontium richterites. European Journal of Mineralogy, 2, $171-175$.

Della Ventura, G., Robert, J.-L., and Bény, J.-M. (1991) Tetrahedrally coordinated $\mathrm{Ti}^{++}$in synthetic Ti-rich potassic richterite: Evidence from 
XRD, FTIR, and Raman studies. American Mineralogist, 76, 1134 1140 .

Della Ventura, G., Robert, J.-L., Bény, J.-M., Raudsepp, M., and Hawthorne, F.C. (1993a) The OH-F substitution in Ti-rich potassium-richterite: Rietveld structure refinement and FTIR and micro-Raman spectroscopic studies of synthetic amphiboles in the system $\mathrm{K}_{2} \mathrm{O}-\mathrm{Na}_{2} \mathrm{O}-\mathrm{CaO}-\mathrm{MgO}-\mathrm{SiO}_{2}-\mathrm{TiO}_{2}-\mathrm{H}_{2} \mathrm{O}-\mathrm{HF}$. American Mineralogist, 78, 980-987.

Della Ventura, G., Robert, J.-L., Raudsepp, M., and Hawthorne, F.C. (1993b) Site occupancies in monoclinic amphiboles: Rietveld structure refinement of synthetic nickel magnesium cobalt potassium richterite. American Mineralogist, 78, 633-640.

Della Ventura, G., Robert, J.-L., and Hawthorne, F.C. (1996) Infrared spectroscopy of synthetic (Ni,Mg,Co)-potassium-richterite. In M.D. Dyar, C. McCammon, and M.W. Schaefer, Eds., Mineral spectroscopy: A tribute to Roger G. Burns, p 55-63. The Geochemical Society.

Graham, C.M., Maresch, W.V., Welch, M.D., and Pawley, A.R. (1989) Experimental studies on amphiboles: A review with thermodynamic perspectives. European Journal of Mineralogy, 1, 535-555.

Groat, L.A., Hawthorne, F.C., Rossman, G.R., and Ercit, T.S. (1995) The infrared spectroscopy of vesuvianite in the $\mathrm{OH}$ region. Canadian Mineralogist, 33, 609-626.

Hawthorne, F.C. (1983a) Characterization of the average structure of natural and synthetic amphiboles. Periodico di Mineralogia, 52, 543-581.

(1983b) The crystal chemistry of the amphiboles. Canadian Mineralogist, 21, 173-480.

Hawthorne, F.C., and Grundy, H.D. (1972) Positional disorder in the A-site of clino-amphiboles. Nature (Physical Science), 235, 72-73.

Hawthorne, F.C., Della Ventura, G., and Robert, J.-L. (1996) Short-range order and long-range order in amphiboles: a model for the interpretation of infrared spectra in the principal OH-stretching region. In M.D. Dyer, C. McCammon, and M.W. Schaefer, Eds., Mineral spectroscopy: A tribute to Roger G. Burns. p. 49-54. The Geochemical Society.

Law, A.D. (1976) A model for the investigation of hydroxyl spectra of amphiboles. In R.G.J. Strens, Ed., The physics and chemistry of minerals and rocks, p. 677-686. Wiley, New York.

Jenkins, D.M., and Hawthorne, F.C. (1995) Synthesis and Rietveld refinement of amphiboles along the join $\mathrm{Ca}_{2} \mathrm{Mg}_{5} \mathrm{Si}_{8} \mathrm{O}_{22} \mathrm{~F}_{2}-\mathrm{NaCa}_{2} \mathrm{Mg}_{4} \mathrm{Ga}_{3}$ $\mathrm{Si}_{6} \mathrm{O}_{22} \mathrm{~F}_{2}$. Canadian Mineralogist, 33, 13-24.

Maresch, W.V., and Czank, M. (1983) Problems of compositional and structural uncertainty in synthetic hydroxyl-amphiboles; with an annotated atlas of the Realbau. Periodico di Mineralogia, 52, 463-542.

(1988) Crystal chemistry, growth kinetics and phase relationships of structurally disordered $\left(\mathrm{Mn}^{2+}, \mathrm{Mg}\right)$-amphiboles. Fortschritte der $\mathrm{Mi}$ neralogie, 66, 69-121.

Maresch, W.V., Czank, M., and Schreyer, W. (1994) Growth mechanisms, structural defects and composition of synthetic tremolite: What are the effects on macroscopic properties? Contributions to Mineralogy and Petrology, 118, 297-313.

Mottana, A., Paris, E., Della Ventura, G., and Robert, J.-L. (1990) Spectroscopic evidence for tetrahedrally-coordinated titanium in richteritic amphiboles. Rendiconti Fisici Accademia Lincei, 9(1), 387-392.

Oberti, R., Sardone, N., Hawthorne, F.C., Raudsepp, M., and Turnock, A.C. (1995) Synthesis and crystal-structure refinement of synthetic fluor-pargasite. Canadian Mineralogist, 33, 25-31.

Paris, E., Mottana, A., Della Ventura, G., and Robert, J.-L. (1993) Titanium valence and coordination in synthetic richterite-Ti-richterite amphiboles. A synchrotron-radiation XAS study. European Journal of Mineralogy, 5, 455-464.
Phillips, R., and Rowbotham, G. (1973) Studies on synthetic alkali amphiboles. Papers and proceedings of the fifth general meeting, I.M.A., Cambridge, 249-254.

Raudsepp, M., Turnock, A.C., Hawthorne, F.C., Sherriff, B.L., and Hartman, J.S. (1987a) Characterization of synthetic pargasitic amphiboles $\left(\mathrm{NaCa}_{2} \mathrm{Mg}_{4} \mathrm{M}^{3+} \mathrm{Si}_{6} \mathrm{Al}_{2} \mathrm{O}_{22}(\mathrm{OH}, \mathrm{F})_{2} ; \mathrm{M}^{3+}=\mathrm{Al}, \mathrm{Cr}, \mathrm{Ga}, \mathrm{Sc}, \mathrm{In}\right)$ by infrared spectroscopy, Rietveld structure refinement, and ${ }^{27} \mathrm{Al},{ }^{29} \mathrm{Si}$, and ${ }^{19} \mathrm{~F}$ MAS NMR spectroscopy. American Mineralogist, 72, 580-593.

Raudsepp, M., Turnock, A.C., and Hawthorne, F.C. (1987b) Characterization of cation ordering in synthetic scandium-fluor-eckermannite, indium-fluor-eckermannite, and scandium-fluor-nyböite by Rietveld structure refinement. American Mineralogist, 72, 959-964.

Raudsepp, M., Hawthorne, F.C., and Turnock, A.C. (1990) Crystal chemistry of synthetic pyroxenes on the join $\mathrm{CaNiSi}_{2} \mathrm{O}_{6}-\mathrm{CaMgSi}_{2} \mathrm{O}_{6}$ (diopside): A Rietveld structure refinement study. American Mineralogist, 75, 1274-1281.

Raudsepp, M., Turnock, A.C., and Hawthorne, F.C. (1991) Amphibole synthesis at low pressure: What grows and what doesn't. European Journal of Mineralogy, 3, 983-1004.

Rietveld, H.M. (1969) A profile refinement method for nuclear and magnetic structures. Journal of Applied Crystallography, 2, 65-71.

Robert, J.-L., Della Ventura, G., and Thauvin, J.-L. (1989) The infrared $\mathrm{OH}$-stretching region of synthetic richterites in the system $\mathrm{Na}_{2} \mathrm{O}-\mathrm{K}_{2} \mathrm{O}$ $\mathrm{CaO}-\mathrm{MgO}-\mathrm{SiO}_{2}-\mathrm{H}_{2} \mathrm{O}-\mathrm{HF}$. European Journal of Mineralogy, 1, 203-211.

Robert, J.-L., Della Ventura, G., Raudsepp, M., and Hawthorne, F.C. (1993) Rietveld structure refinement of synthetic strontium-rich potassium-richterites. European Journal of Mineralogy, 5, 199-206.

Sakthivel, A., and Young, R.A. (1991) User's guide to programs DBWS9006 and DBWS-9006PC for Rietveld analysis of X-ray and neutron powder diffraction patterns.

Shannon, R.D. (1976) Revised effective ionic radii and systematic studies of interatomic distances in halides and chalcogenides. Acta Crystallographica, A32, 751-767.

Skogby, H., and Rossman, G.R. (1991) The intensity of amphibole OH bands in the infrared absorption spectrum. Physical Chemistry of Minerals, 18, 64-68.

Strens, R.G.J. (1966) Infrared study of cation ordering and clustering in some $(\mathrm{Fe}, \mathrm{Mg})$ amphibole solid solutions. Chemical Communications, $15,519-520$.

Strens, R.G.J. (1974) The common chain, ribbon, and ring silicates. In V.C. Farmer, Ed., The infrared spectra of minerals. Mineralogical Society, London, U.K.

Virgo, D. (1972) Preliminary fitting of ${ }^{57} \mathrm{Fe}$ Mössbauer spectra of synthetic $\mathrm{Mg}-\mathrm{Fe}$ richterites. Carnegie Institute of Washington Year Book, 71, 513-516.

Welch, M.D., Kolodziejski, W., and Klinowski, J. (1994) A multinuclear NMR study of synthetic pargasite. American Mineralogist, 79, 261268.

Wiles, D.B., and Young, R.A. (1981) A new computer program for Rietveld analysis of X-ray powder diffraction patterns. Journal of Applied Crystallography, 14, 149-151.

Young, R.A., MacKie, P.E., and Von Dreel, L.P. (1977) Application of the pattern-fitting structure-refinement method to X-ray powder diffractometer patterns. Journal of Applied Crystallography, 10, 262.

Manuscript ReCeived May 2, 1996

ManusCRiPt ACCEPTEd DeCEMber 2, 1996 